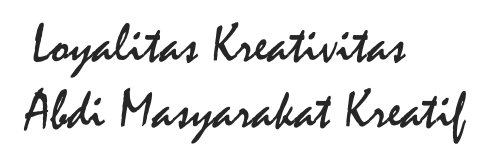

P-ISSN 2722-2101, E-ISSN 2722-4201

Program Studi Ekonomi Manajemen Universitas Pamulang

Jurnal LOKABMAS Kreatif Vol. 01, No. 02, Hal. 16-23

Email:jurnalkreatif.manajemen@gmail.com

\title{
PENDEKATAN MANAJEMEN STRATEGIK DALAM RANGKA MENINGKATKAN MINAT WIRAUSAHA MASYARAKAT KELURAHAN REMPOA TANGERANG SELATAN
}

\author{
Krisnaldy ,Amoen Soepandi, Bambang Purnomo Yanuarso, R.r. Ayu Metarini, \\ Ugeng Budi Haryoko \\ Dosen Ekonomi Fakultas Ekonomi Universitas Pamulang \\ Email : dosen01890@unpam.ac.id Soepandi.amun@gmail.com, \\ dosen02142@unpam.ac.id, meta ayurini@yahoo.com, ugengbudiunpam@gmail.com
}

\begin{abstract}
ABSTRAK
Pengabdian ini berjudul Pendekatan Manajemen Strategik Dalam Rangka meningkatkan Minat Wirausaha Masyarkatdi kelurahan Rempoa Tangerang Selatan

Tujuan pengabdian ini adalah untuk Membantu memberikan arahan terhadap kepada keluarga, wanita dalam hal pengembangan kewirausahaan dan ukm dan Memberikan semangat dan motivasi bagi kepala keluarga,wanita dan anak anak dalam menjalani kehidupan yang lebih baik. Metode pelaksanaan pengabdian ini dilakukan dalam beberapa kegiatan yaitu tahap survei yaitu sosialisasi dilakukan dengan menyusun berbagai hal yang akan disampaikan pada saat kegiatan pengabdian yang akan dilakukan yang meliputi: penyusunan materi yang akan diberikan, penyusunan jadwal pemberian materi, pembagian tugas tim pengabdian dan survei ke lokasi pengabdian. Tahap sosialisasi yaitu sebelum kegiatan pengabdian dilaksanakan terlebih dahulu dilakukan tahap sosialisasi yaitu melakukan silaturahmi dengan perwakilan lurah, menyampaikan maksud dan tujuan pengabdian ini. Pada tahap ini juga dilakukan jalinan kerjasama dan menentukan jadwal kegiatan pengabdian. Tim pelaksana kegiatan pengabdian pada masyarakat adalah dosen Fakultas Ekonomi jurusan manajemen sebanyak 5 orang. Tim pengabdian memberikan materi tentang penyuluhan pengembangan kewirausahaan dan ukm kepada ibu ibu pkk di Jakarta Selatan dan akan memberikan pelatihan disana oleh dosen UNPAM.

Kesimpulan dari pengabdian ini adalah Peserta sangat antusias terhadap pelakasanaan kegiatan ini sehingga membangkitkan keinginan untk berwirausaha. Harapan kami dengan pengabdian ini dapat membuka wawasan masyarakat yang diperoleh adalah bertambahnya keilmuan bagi para Para Masyarakat dan Ilmu yang diperoleh pada Pengabdian Masyarakat kali ini diharapkan mampu memberikan semangat baru bagi kita dalam menyampaikan materi dan motivasi serta berkontribusi bagi generasi muda, baik dilingkungan sekolah, kampus dan keluarga
\end{abstract}

Kata Kunci: Kewirausahaan, Strategi, Pelatihan

ABSTRAC

This service is titled entrepreneurship training to improvement people in the Rempoa subdistrict of South tangerang. 
The purpose of this service is to help provide direction to families, women in terms of entrepreneurship and SME development and to provide encouragement and motivation for family heads, women and children in living a better life. The method of implementing this service is carried out in a number of activities, namely the survey stage, namely the socialization carried out by compiling various things that will be delivered at the time of service activities that will be carried out which include: preparation of material to be given, preparation of material delivery schedule, division of tasks of the service team and survey to the location devotion. The socialization phase is before the community service activity is carried out first, the socialization stage is to do a friendly gathering with representatives of the lurah, conveying the aims and objectives of this service. At this stage also carried out the fabric of cooperation and determine the schedule of service activities. The implementing team of community service activities are 5 people from the Faculty of Economics majoring in management. The dedication team provides materials on counseling entrepreneurship development and SMEs to the ladies in South Jakarta and will provide training there by UNPAM lecturers.

The conclusion of this service is that Participants are very enthusiastic about the implementation of this activity so that it arouses the desire for entrepreneurship. Our hope with this dedication can open community insights gained is the increase of knowledge for the Society and Knowledge obtained at this time Community Service is expected to provide new enthusiasm for us in conveying material and motivation and contribute to the young generation, both in the school, campus environment and family

\section{Keywords: Etrepreneurship, Strategic, Coaching}

\section{PENDAHULUAN}

Entrepreneurship yang dalam Bahasa Indonesia lebih dikenal dengan terminologi kewirausahaan adalah hal yang digadang-gadang mampu membantu percepatan pertumbuhan ekonomi di Indonesia. Seorang sosiolog bernama David McCleland pernah mengatakan jika sebuah negara ingin makmur, maka minimal $2 \%$ dari penduduk negara tersebut harus menjadi wirausahawan. Sayangnya, hingga Maret 2015 lalu jumlah wirausaha di Indonesia baru sekitar 1,65\%. Jumlah ini kalah jauh dari negara-negara tetangga kita, misalnya Singapura 7\%, Malaysia 5\%, dan Thailand 4\%. Untuk menjadi seorang wirausahawan, seseorang semestinya harus mengetahui terlebih dahulu apa tujuan kewirausahaan yang hendak dibangunnya. Tujuan kewirausahaan penting untuk dipikirkan untuk seseorang menjadi wirausaha sukses. Dalam artikel kali ini, kita akan membahas mengenai kewirausahaan dan berbagai tujuan kewirausahaan supaya seorang wirausaha dapat membangun bisnis yang sesuai dengan tujuan kewirausahaan tersebut.

\section{PENGERTIAN KEWIRAUSAHAAN}

Entreprenurship Merupakan sebuah proses seseorang dalam mengejar peluang yang ada untuk memenuhi kebutuhan dan keinginannya. Peluang tersebut diwujudkan dalam bentuk inovasi dengan memanfaatkan berbagai sumber daya yang ada. Kewirausahaan merupakan proses yang dinamis, yakni menciptakan sesuatu dengan menggunakan waktu dan kegiatan disertai modal, jasa dan tentunya 
resiko. Seperti yang telah dibahas sebelumnya, kewirausahaan dapat membantu sebuah negara untuk berkembang secara ekonomi. Selain mengurangi jumlah pengangguran, kewirausahaan juga dapat meningkatkan jumlah pendapatan pajak negara. Dengan adanya kewirausahaan, masyarakat juga dapat menjadi lebih mandiri, tidak lagi tergantung pada gaji yang dibayarkan oleh negara.

Wirausaha merupakan profesi yang penuh resiko. Sedikit kesalahan dapat membawa bentuk kerugian yang luar biasa. Meskipun begitu, menjadi wirausaha tentunya memiliki berbagai keuntungan, seperti Menjadi bos dalam perusahaan sendiri Pada dasarnya, semua orang bisa dan berhak menjadi wirausaha. Tetapi terdapat tiga sasaran utama kewirausahaan, yaitu: Sasaran kewirausahaan yang pertama adalah instansi pemerintah dengan kegiatan usaha $($ BUMN = Badan Usaha Milik Negara), organisasi profesi dankelompok masyarakat.Sasaran kewirausahaan kedua adalah para pelaku ekonomi, terdiri dari pe ngusaha kecil dan koperasi. Sasaran kewirausahaan ketiga adalahgenerasi muda, anak-anak putus sekolah, dan calon wirausahawanBisnis tanpa tujuan kewirausahaan ibarat bangunan tanpa pondasi yang kokoh. Bisnis tersebut mungkin saja bisa terbangun, namun kekuatannya akan sangat rapuh. Tanpa tujuan kewirausahaan, sebuah bisnis akan mudah hancur ketika dihadapkan pada situasi yang sulit. Karena itulah, tujuan kewirausahaan merupakan hal yang sangat penting untuk disusun sebelum seseorang memutuskan untuk membangun sebuah bisnis. banyak sekali tujuan kewirausahaan yang dapat dijadikan panduan oleh setiap pembisnis. Tujuan kewirausahaan tentunya berbeda-beda, tergantung dari individu yang ada di belakangnya. Secara umum, tujuan kewirausahaan tidak hanya baik untuk diri wirausahawan sendiri. Tujuan kewirausahaan sering kali lebih luas, yakni tujuan kewirausahaan dapat pula baik untuk pihak-pihak lain yang berada jauh dari bisnis tersebut. Tujuan kewirausahaan yang pertama adalah meningkatkan jumlah wirausaha berkualitas. Tujuan kewirausahaan ini berdasarkan pada pemikiran jika seorang pembisnis tentunya membutuhkan sumber daya manusia lain untuk membantunya membangun perusahaan. Dengan bimbingan yang tepat, sumber daya manusia tersebut tidak hanya dapat diberdayakan kemampuannya, namun juga dapat dilatih dan dikembangkan supaya dapat menjadi calon wirausaha yang berkualitas. Tujuan kewirausahaan ini tidak menutup kemungkinan jika suatu hari nanti, "si anak buah" akan mampu mandiri dan membuka usahanya sendiri. Setelah tujuan kewirausahaan ini terwujud, maka sang pembisnis telah berhasil meningkatkan jumlah wirausaha berkualitas. Wirausahawan dapat dikategorikan sebagai orang-orang yang memiliki jiwa tangguh, kompetitif, dan pandai mencari peluang. Semangat wirausaha yang tidak pernah padam ini sangat baik jika mampu ditularkan ke masyarakat sebagai sebuah tujuan kewirausahaan yang selanjutnya. Tujuan kewirausahaan membudayakan semangat wirausaha di masyarakat dapat diwujudkan dengan cara yang sangat sederhana, yaitu dengan bersikap seperti apa adanya seorang entrepreneur. Sikap tersebut tentunya akan menginspirasi dan membuat masyarakat tergerak untuk 
mencoba berwirausaha. Sikap tangguh dan tidak mudah menyerah juga sebaiknya diperlihatkan supaya tujuan kewirausahaan ini dapat membangun semangat orang-orang muda di masyarakat supaya mau bekerja keras untuk mendapatkan keberhasilan.

kewirausahaan yang selanjutnya adalah untuk memajukan dan menyejahterakan masyarakat. Semakin sukses dan semakin berkembangnya sebuah bisnis, pasti akan membutuhkan semakin banyak sumber daya manusia. Hal ini berarti semakin banyaknya lapangan pekerjaan yang terbuka bagi masyakarat. Dengan berkurangnya jumlah pengangguran, berarti sebuah bisnis telah berhasil mewujudkan tujuan kewirausahaan untuk memajukan dan menyejahterakan masyarakat.

\section{RUMUSAN MASALAH}

Dengan mempertimbangkan latar belakang yang telah diutarakan diatas kami berinisiatif untuk membentuk pengabdian masyarakat bagi masyarakat dalam rangka menerapkan managemen strategik meningkatkan minat wirausaha di kelurahan rempoa oleh Dosen UNPAM yang beralamatkan di kelurahan Rempoa tangerang Selatan

\section{TUJUAN PELAKSANAAN}

1. Membantu memberikan pelatihan berwirausaha kepada Masyarakat sekitar kelurahan Rempoa

2. Memberikan semangat dan motivasi serta penerapan managemen strategic. bagi masyarakat sekitar keluarahan rempoa dalam menjalankan / memulai usaha

\section{TINJAUAN PUSTAKA}

\section{Pengertian Manajemen}

Pengertian manajemen secara umum dapat disimpulkan dari beberapa definisi menurut para ahli. Hal ini karena ada banyak versi definisi manajemen. Misalnya saja manajemen menurut seorang ahli bernama Mary Parker Follet yang mendefinisikan manajemen sebagai seni merampungkan pekerjaan melalui orang lain. Dari definisi tersebut didapati bahwa seseorang yang bertugas sebagai manajer dapat mengarahkan dan mengatur orang lain guna mencapai tujuan organisasi.

Di sisi lain, James A.F Stoner mendefinisikan manajemen sebagai proses pengorganisasian, perencanaan, dan penggunaan SDM supaya mencapai tujuan organisasi yang sudah ditetapkan.

Secara umum, pengertian manajemen merupakan suatu seni dalam ilmu dan pengorganisasian seperti menyusun perencanaan, membangun organisasi dan pengorganisasiannya, pergerakan, serta pengendalian atau pengawasan. Bisa juga diartikan bahwa manajemen merupakan suatu ilmu pengetahuan yang sistematis agar dapat memahami mengapa dan bagaimana manusia saling bekerja sama agar dapat menghasilkan sesuatu yang bermanfaat bagi orang lain maupun golongan tertentu dan masyarakat luas. Secara etimologis, pengertian manajemen merupakan seni untuk melaksanakan dan mengatur. Manajemen ini juga dilihat sebagai ilmu yang mengajarkan proses mendapatkan tujuan dalam organisasi, sebagai usaha bersama dengan beberapa orang dalam organisasi tersebut. Sehingga, ada orang yang merumuskan dan melaksanakan 
tindakan manajemen yang disebut dengan manajer.

\section{Fungsi Manajemen}

Pada dasarnya, fungsi manajemen dibagi menjadi tiga, yaitu:

\section{Perencanaan (planning)}

Pernecanaan adalah memikirkan apa yang akan dikerjakan dengan sumber yang dimiliki. Perencanaan dilakukan untuk menentukan tujuan perusahaan secara keseluruhan dan cara terbaik untuk memenuhi tujuan itu. Manajer mengevaluasi berbagai rencana alternatif sebelum mengambil tindakan dan kemudian melihat apakah rencana yang dipilih cocok dan dapat digunakan untuk memenuhi tujuan perusahaan. Perencanaan merupakan proses terpenting dari semua fungsi manajemen karena tanpa perencanaan, fungsi-fungsi lainnya tak dapat berjalan.

\section{Pengorganisasian (organizing)}

Pengorganisasian dilakukan dengan tujuan membagi suatu kegiatan besar menjadi kegiatan-kegiatan yang lebih kecil. Pengorganisasian mempermudah manajer dalam melakukan pengawasan dan menentukan orang yang dibutuhkan untuk melaksanakan tugas-tugas yang telah dibagi-bagi tersebut. Pengorganisasian dapat dilakukan dengan cara menentukan tugas apa yang harus dikerjakan, siapa yang harus mengerjakannya, bagaimana tugas-tugas tersebut dikelompokkan, siapa yang bertanggung jawab atas tugas tersebut, dan pada tingkatan mana keputusan harus diambil.

\section{Pengarahan (directing)}

Pengarahan adalah suatu tindakan untuk mengusahakan agar semua anggota kelompok berusaha agar dapat mencapai sasaran sesuai dengan perencanaan manajerial dan usaha.

\section{UNSUR-UNSUR MANAJEMEN}

Setiap perusahaan memiliki unsur-unsur untuk membentuk sistem manajerial yang baik. Unsur-unsur inilah yang disebut unsur manajemen. Jika salah satu diantaranya tidak sempurna atau tidak ada, maka akan berimbas dengan berkurangnya upaya untuk mencapai

\section{TINJAUAN PUSTAKA}

\section{Pengertian Manajemen Sumber Daya Manusia}

Manajemen adalah ilmu dan seni yang megatur proses pemanfaatan sumber daya manusia dan sumbersumber daya lainya secara efektif dan efesien untuk mencapai suatu tujuan tertentu.

Manajemen sumber daya manusia merupakan bagian dari ilmu manajemen yang memfokuskan perhatianya pada pengaturan peranan sumber daya manusia dalam kegiatan organisasi. Hal ini dikarnakan dalam mencapai tujuanya, organisasi memerlukan sumber daya manusia sebagai pengeelola sistemnya, dan agar sistem ini berjalan, dalam pengelolaanya diperlukan beberapa aspek penting, seprti pelatihan, pengembangan, motivasi dan aspek-aspek lainya. Hal ini yang menjadikan manajeman sumber daya manusia sebagai salah satu indikator penting pencapaian tujuan organisasi secara efektif dan efisien.( mila badriah, S.E.,M.M, 15: 2015).

Manusia selalu berperan aktif dan dominan dalam kegiatan organisasi 
karena manusia menjadi perencana, pelaku, dan penentu terwujudanya tujuan organisasi. Tujuan tidak mungkin terwujud tanpa peran aktif tanpa peran karyawan meskipun alat-alat yang dimiliki oleh perusahaan begitu canggih. Alat-alat canggih perusahaan tidak ada manfaatnya bagi perusahaan, jika peran aktif karyawan tidak di ikut sertakan. Mengatur karyawan merupakan hal yang sulit dan kompleks karena mereka mempunyai pikiran, perasaan, status, keinginan, dan latar belakang yang heterogen yang dibawa kedalam suatu organisasi. Karyawan tidak dapat di atur dan dikuasai sepenuhnya seperti mengatur mesin, moda, dan gedung.

Manajemen sumber daya
manusia merupakan bagian dari
manajemen. Oleh karna itu, teori-teori
manajemen umum manjadi dasar
pembahasaannya mengenai pengaturan
peranaan manusia dalam menentukan
tujuan yang optimal.

Pengaturan itu meliputi masalah perencanaan (human resources planning), pengorganisasian, pengarahaan,kompena sasi,pengintregrasian,pemeliharaan,kedis iplinan dan pemberhentian tenaga kerja untuk membantu terwujudnya tujuan perusahaan, karyawan, dan masyarakat.

Pengertian manajeman sumber daya manusia menurut malyu S.P. hasibuan ( 2005: 10 ) yang menyatakan bahwa :

"manajeman sumber daya manusia adalah ilmu dan seni yang mengatur hubungan dan peranan tenaga kerja yang efektif dan efisien membantu terwujudnya tujuan perusahaan, karyawan, dan masyarakat".

\section{METODE PELAKSANAAN}

Metodepelaksanaan pengabdian ini dilakukan dalam beberapa kegiatan yaitu tahap survei yaitu sosialisasi dilakukan dengan menyusun berbagai hal yang akan disampaikan pada saat kegiatan pengabdian yang akan dilakukan yang meliputi: penyusunan materi yang akan diberikan, penyusunan jadwal pemberian materi, pembagian tugas tim pengabdian dan survei ke lokasi pengabdian. Tahap sosialisasi yaitu sebelum kegiatan pengabdian dilaksanakan terlebih dahulu dilakukan tahap sosialisasi yaitu melakukan silaturahmi dengan ketua yayasan, menyampaikan maksud dan tujuan pengabdian ini. Pada tahap ini juga dilakukan jalinan kerjasama dan menentukan jadwal kegiatan pengabdian. Tim pelaksana kegiatan pengabdian pada masyarakat adalah dosen Fakultas Ekonomi jurusan manajemen sebanyak 5 orang. Tim pengabdian memberikan materi tentang managemen strategi dalam rangka meningkatkan minat wirausaha kepada masyarakat disekitar Kelurahan Rempoa

\section{HASIL DAN PEMBAHASAN}

Pengabdian Masyarakat (LPPM) Universitas Pamulang yang dilakukan oleh dosen-dosen program studi Manajemen telah berjalan dengan lancar dan mendapat sambutan hangat dari tempat pelaksanaan kegiatan ini yaitu di Kelurahan Rempoa

$$
\text { Harapan kami dengan }
$$

pengabdian ini dapat membuka wawasan masyarakat yang diperoleh adalah bertambahnya keilmuan bagi para Para Masyarakat dan Ilmu yang diperoleh pada Pengabdian Masyarakat kali ini diharapkan mampu memberikan semangat baru bagi kita dalam menyampaikan materi dan motivasi serta berkontribusi bagi generasi muda, baik 
dilingkungan sekolah, kampus dan keluarga.

\section{KESIMPULAN DAN SARAN Kesimpulan}

Peserta memahami dan antusias tingi dalam mengikuti pelatihan kewirausahaan ini dan semakin yakin memulai usaha.

\section{Saran}

Setelah pengabdian ini diharapkan peserta dapat memiliki hidup yang lebih sehat secara rohani dan membangun keluarga yang lebih harmonis serta mengajak teman/peserta lainnya untuk ikut menjadi relawan dalam memberantas tindak kekerasan terhadap wanita dan anak-anak. Tim pengabdian agar terus melakukan kegiatan-kegiatan serupa secara berkesinambungan di masa yang akan datang

\section{DAFTAR PUSTAKA}

Arikunto, Suharsimi. 2008. DasarDasar Evaluasi Pembelajaran. Jakarta: Bumi Aksara. 308 hlmn.

Kartini Kartono, 2008, Pemimpin dan kepemimpinan. Jakarta: Raja Grafindo Persada

Pasaribu, V. L. D., Agrasadya, A., Shabrina, N., \& Krisnaldy, K. (2020). MENJADI ENTERPRENEUR MUDA YANG MEMILIKI JIWA LEADERSHIP UNTUK MENGHADAPI MASA DEPAN. Abdi Laksana, 1(1)

Pasaribu, V. L. D., Elburdah, R. P., Sudarso, E., \& Fauziah, G. (2020). PENGGUNAAN MANAJEMEN WAKTU TERHADAP PENINGKATAN PRESTASI BELAJAR DI SMP ARAISIYAH. Jurnal ABDIMAS, 1(1)

Pasaribu, V. L. D., Susanti, F., \& Hartuti, E. T. K. (2019). MEMOTIVASI SISWA DAN

\section{SISWI SMK LETRIS INDONESIA DI DALAM MENENTUKAN PILIHAN UNTUK MELANJUTKAN PENDIDIKAN ATAU BEKERJA SETELAH LULUS SEKOLAH. Jurnal Pengabdian Dharma Laksana, 1(2), 161-172.}

Pasaribu, V. L. D., Oktrima, B., Prabowo, B., Arianto, N., \& Haryoko, U. B. (2020). PROGAM PENDAMPINGAN DAN PENYELENGGARAAN PENDIDIKAN ANAK PADA USIA DINI TERHADAP PRESTASI BELAJAR DILINGKUNGAN RT 020 RW 009. KEL GIRI PENI. KEC WATES. YOGYAKARTA. JURNAL LOKABMAS KREATIF, 1(1), 71-75.

Pasaribu, V. L. D., Sulaiman, S., Sutiman, S., Thaharudin, T., \& Purnomo, B. Y. (2020). PENGENALAN LETAK POSYANDU TERDEKAT DIKELURAHAN PISANGAN DENGAN MANAJEMEN PEMASARAN REVOLUSI 4.0 UNTUK MENINGKATKAN PENGETAHUAN MASYARAKAT LETAK DAN FUNGSI POSYANDU TERDEKAT PADA KELURAHAN PISANGAN. DEDIKASI PKM, 1(1), 105-110.

Pasaribu, V. L. D., \& Krisnaldy, K. (2019). Manajemen Risiko dan Asuransi.

\section{DOKUMENTASIFOTO KEGIATAN}

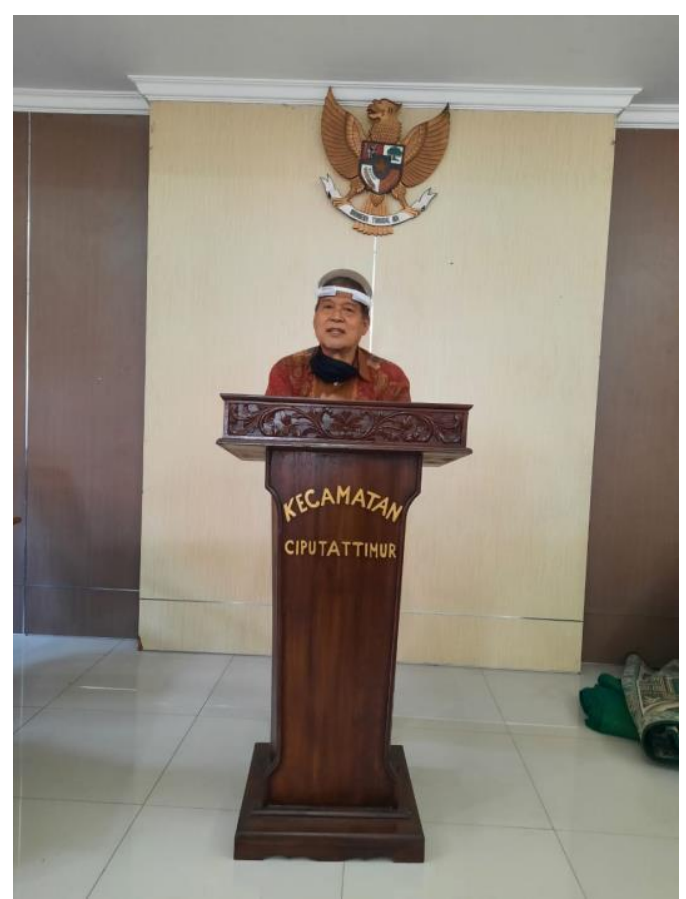



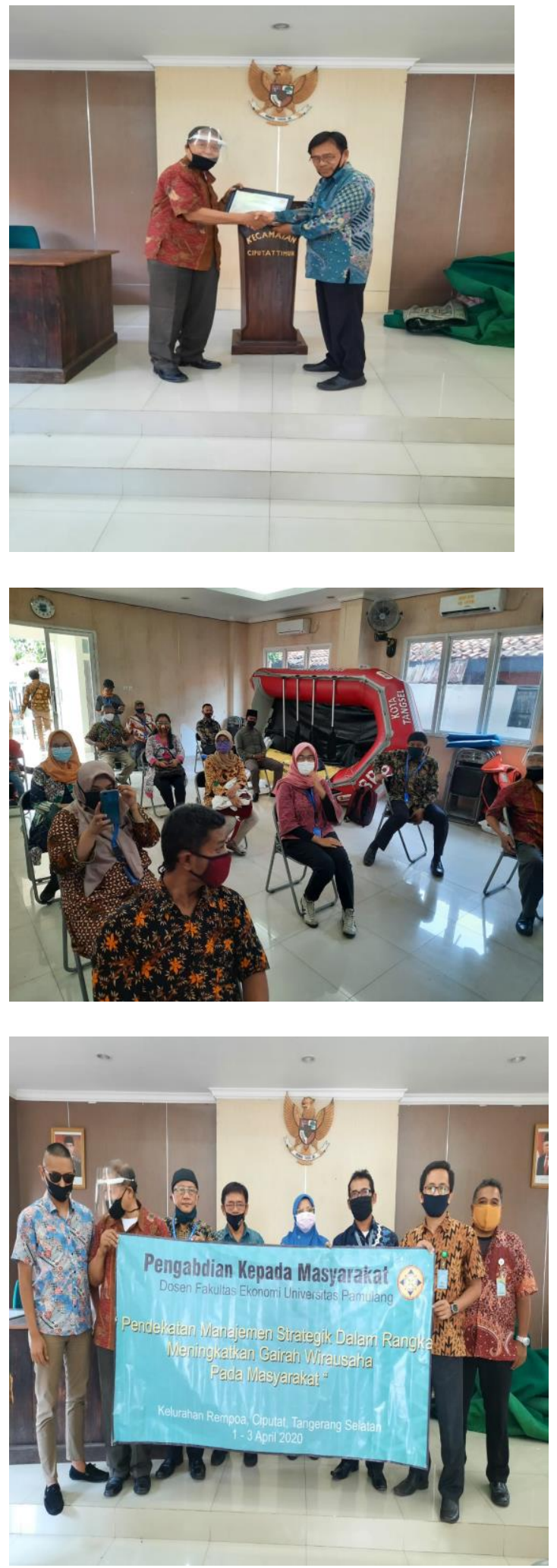